\title{
Lactobacillus vini sp. nov., a wine lactic acid bacterium homofermentative for pentoses
}

Correspondence
Rosa Aznar
rosa.aznar@uv.es

Several species of lactic acid bacteria have been described by different authors as being associated with the winemaking process (Davis et al., 1985; Wibowo et al., 1985; Fleet, 1993; Rodas et al., 2005). Some of them are beneficial for wine quality, whereas others have been described as detrimental (Sponholz, 1993; Edwards et al., 1998).

In 1978, P. Barre isolated one wine lactobacillus from hightemperature fermenting grape must (Barre, 1978), named as

\footnotetext{
Published online ahead of print on 4 November 2005 as DOI 10.1099/ ijs.0.63877-0.

tThese authors contributed equally to this work and are considered joint first authors.

Abbreviations: 16S-ARDRA, amplified 16S rDNA restriction analysis; ISR, internal spacer region; RAPD, random amplified polymorphic DNA.

A table detailing phenotypic traits of Lactobacillus vini and its closest phylogenetic neighbours L. mali, L. nagelii and L. satsumensis, and figures showing phylogenetic trees constructed using the maximumparsimony and maximum-likelihood methods and a dendrogram derived from the comparison of combined molecular techniques' patterns obtained from wine lactic acid bacteria and reference strains are available as supplementary material in IJSEM Online.
}

Mont 4, that was deposited at the Deustche Sammlung von Micro-organismem und Zellkulturen GmbH (DSMZ) as Lactobacillus sp. DSM 20605. Afterwards, this bacterium was incorporated in the Spanish Type Culture Collection (CECT) from DSMZ as Lactobacillus sp. CECT 5924. Chenoll et al. (2003) included it in a molecular taxonomic study in order to establish an rRNA-based identification scheme for Carnobacterium, Lactobacillus, Leuconostoc and Pediococcus species. In this study, the authors reported that strain CECT 5924 (=Mont $4=$ DSM 20605) had singular rRNA-RFLP, internal spacer region (ISR)-PCR and ISRRFLP profiles that allowed its differentiation from the rest of the analysed members of the genus Lactobacillus. In addition, and based on 16S rRNA gene sequence analysis, it was suggested that this strain might represent a novel species. Later on, Rodas et al. (2005), following an extensive polyphasic study of wine lactobacillus strains, found a cluster of wine lactobacilli that showed $100 \% 16 \mathrm{~S}$ rRNA gene sequence similarity value with strain Mont 4 (=CECT 5924). The closest phylogenetic neighbours of strain CECT 5924 are Lactobacillus mali, Lactobacillus nagelii and the recently described novel species Lactobacillus satsumensis, with $95 \cdot 1,95 \cdot 3$ and $95 \cdot 6 \%$ sequence similarity, respectively. 
This study presents the phenotypic and genotypic characterization of wine and reference strains, including DNADNA hybridization experiments. On the basis of these results, a novel species of the genus Lactobacillus, Lactobacillus vinisp. nov. is proposed, with strain Mont $4^{\mathrm{T}}\left(=\mathrm{DSM} 20605^{\mathrm{T}}=\right.$ CECT $5924^{\mathrm{T}}$ ) as the type strain.

In addition to strain Mont $4^{\mathrm{T}}\left(=\mathrm{DSM} 20605^{\mathrm{T}}=\mathrm{CECT}\right.$ $5924^{\mathrm{T}}$ ), wine strains 116 (CECT 7072), 119 and 209P were isolated from fermenting red grape Bobal must, whereas strains 154 and 155 came from fermenting red grape Tempranillo must (Rodas et al., 2005), both musts were used for winemaking in the Utiel-Requena Origin Denomination in Spain. These strains and the reference strains L. mali CECT 4149, L. nagelii CECT $5983^{\mathrm{T}}$ and $L$. satsumensis DSM $16230^{\mathrm{T}}$ were grown in modified MRS (mMRS) broth that consisted of MRS (Scharlab) supplemented with L-cysteine hydrochloride $\left(0.5 \mathrm{~g} \mathrm{l}^{-1}\right)$ as described by Rodas et al. (2003). They were incubated at $28{ }^{\circ} \mathrm{C}$ in sealed plastic bags, and stored in $20 \%(\mathrm{v} / \mathrm{v})$ glycerol at $-80^{\circ} \mathrm{C}$ or lyophilized. Phenotypic characterization of strains was done following standardized methods.

Colonies grown on mMRS agar plates at $28^{\circ} \mathrm{C}$ for 4 days are $0 \cdot 7-1 \cdot 5 \mathrm{~mm}$ in diameter, white, smooth, circular and convex with entire edges. Cells are rod-shaped, 0 49-0 82 $\times 1 \cdot 36-2 \cdot 8 \mu \mathrm{m}$ in size, a few cells are even longer, and the mean value is $0 \cdot 66 \times 2 \cdot 14 \mu \mathrm{m}$ in size. Cells are motile, nonspore-forming and occur mainly in pairs but also in short chains of up to five cells. Although a few cells grown in mMRS are motile when observed on wet mounts, no flagella are observed under the Heimbrook's staining method (Heimbrook et al., 1989). All strains are Gram-positive, catalase-negative, facultative anaerobes. They form DLlactate from glucose, as determined by the L-lactic kit (Roche) and HPLC (Frayne, 1986), but not gas and they do not ferment gluconate, thus being considered as homofermentative. However, all of them are able to ferment Larabinose and Mont $4{ }^{\mathrm{T}}$ ferments D-ribose as well, exclusively yielding DL-lactate as the end product. The molar ratios are $1 \cdot 57: 1 \cdot 70$ (lactate:pentose) for all strains and pentoses, near to the theoretical 1.67 molar ratio lactate:pentose value. These results are in agreement with those obtained by Barre (1978), and verified by Kandler (1983) and Picataggio et al. (1998) for strain Mont $4^{\mathrm{T}}$. Moreover, Picataggio et al. (1998) demonstrated that Mont $4^{\mathrm{T}}$ had transaldolase and transketolase activities, allowing it to use pentose sugars via an inducible pentose phosphate pathway. This pathway, which exclusively yields lactate as a final product, is different from the 6-phosphogluconate pathway used by heterofermentative facultative lactobacilli.

Strains $116,119,154,155,209 \mathrm{P}$ and Mont $4^{\mathrm{T}}$ grow at 25, 37 and $45^{\circ} \mathrm{C}$ but not at 5 or $15^{\circ} \mathrm{C}$. They grow at $\mathrm{pH} 3 \cdot 7,4 \cdot 5$ and 8.0 and in medium with $5 \%(\mathrm{w} / \mathrm{v}) \mathrm{NaCl}$ added but not with $10 \%(\mathrm{w} / \mathrm{v}) \mathrm{NaCl}$. None of them produce exopolysaccharides from sucrose and only strains 116 and 119 are able to produce ammonia from arginine.
Fermentation profiles of the wine and reference strains were tested in API 50 CHL galleries (bioMérieux) according to the manufacturer's instructions. Strains were incubated up to 5 days at $28^{\circ} \mathrm{C}$. They are shown together with other phenotypic traits in Supplementary Table S1 available in IJSEM Online. Strains 116 and 155 do not ferment cellobiose when tested in the API 50 CHL gallery, but they do when assayed in MRS fermentation broth supplemented with $0.5 \%(\mathrm{w} / \mathrm{v})$ cellobiose (Rodas et al., 2005), and therefore we consider all strains positive for this test. Strains present different fermentative abilities for the following carbohydrates: ribose is only fermented by strain Mont $4^{\mathrm{T}}$; galactose and D-tagatose are fermented by strains 116, 119, 155 and 209P; strain 154 ferments rhamnose and splits arbutin; and methyl $\alpha$-D-mannoside is fermented by all strains with the exception of Mont $4^{\mathrm{T}}$. API $50 \mathrm{CHL}$ profiles were analysed with the BioNumerics 2.5 (Applied Maths) software using the Simple Matching similarity coefficient and the unweighted pair group method using arithmetic averages (UPGMA). Strains 116, 119, 155 and 209P share an identical fermentation profile, being slightly different from the other Spanish strain, 154 (data not shown). Therefore, strain 116 was chosen as a representative of these four strains and compared with strains 154 and Mont $4^{\mathrm{T}}$ in further analysis.

As stated in the online catalogue of DSMZ (http://www. dsmz.de), the cell-wall peptidoglycan of strain Mont $4^{\mathrm{T}}$ $\left(=\right.$ DSM $20605^{\mathrm{T}}=$ CECT $\left.5924^{\mathrm{T}}\right)$ is L-Lys-D-Asp.

The $\mathrm{G}+\mathrm{C}$ content of the type strain was determined by HPLC at DSMZ, following the procedure of Mesbah et al. (1989). Strain Mont $4^{\mathrm{T}}$ has a G $+\mathrm{C}$ content of $39 \cdot 4 \mathrm{~mol} \%$, a value within the range $(32-53 \mathrm{~mol} \%)$ established for the genus Lactobacillus.

GenBank accession numbers of the 16S rRNA gene sequences of about $1500 \mathrm{bp}$ corresponding to strain Lactobacillus sp. CECT 5924 ${ }^{\mathrm{T}}$ (AJ576009) and wine strains 116 (AY681131) and 154 (AY681132) were published in previous studies (Chenoll et al., 2003; Rodas et al., 2005). Subsequent sequence analysis was conducted using the ARB program package (Ludwig et al., 2004). Sequence similarity values were calculated by comparing nucleotides at the corresponding positions, and, following the recommendations of Ludwig et al. (1998), three alternative treeing methods (neighbour-joining, maximum-parsimony and maximum-likelihood) and data subsets were employed using the corresponding ARB tools. The phylogenetic analysis established that the wine strains 116 and 154 showed $99 \cdot 5 \%$ 16S rRNA gene sequence similarity to that of strain Mont $4^{\mathrm{T}}$. The three sequences formed a tight clade in the vicinity of $L$. mali, $L$. nagelii and $L$. satsumensis sequences. The tree shown in Fig. 1 was constructed using the neighbour-joining method. When other tree reconstruction methods were applied, the relative position of some branches varied slightly (see Supplementary Fig. S1 available in IJSEM Online); however, there is no doubt about the independent phylogenetic position of the group formed by strains Mont $4^{\mathrm{T}}, 116$ and 154. Sequence similarities with all members of the 


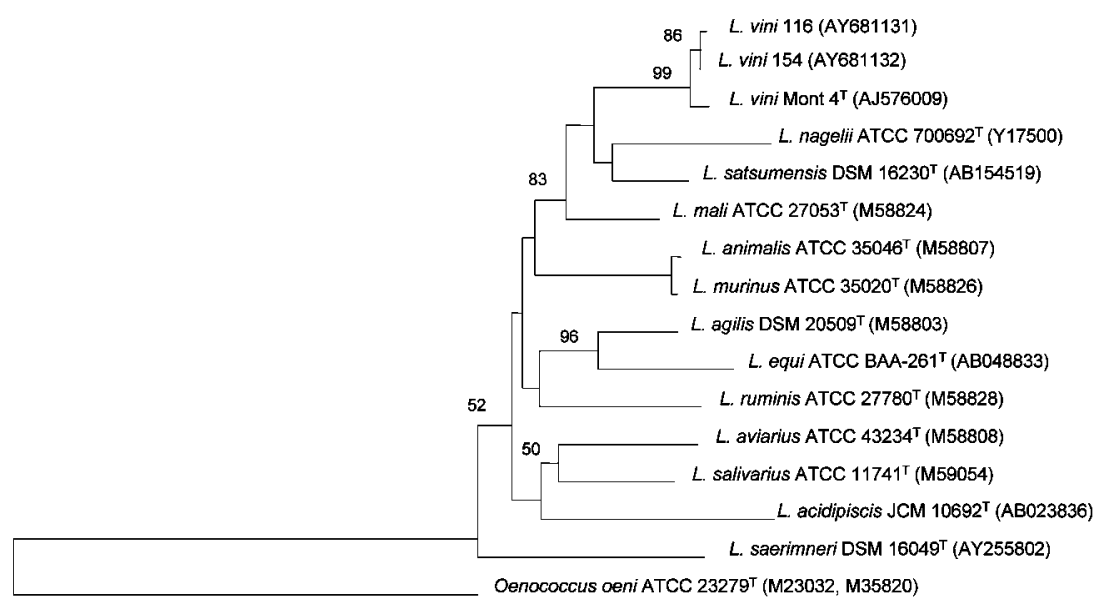

$0 \cdot 10$
Fig. 1. Phylogenetic tree constructed using the neighbour-joining method based on rRNA gene sequences. Lactobacillus vini strains Mont $4^{\top}, 116$ and 154 grouped together within the Lactobacillus casei cluster of micro-organisms (see Collins et al., 1991) and close to strains $L$. nagelii CECT $5983^{\top}$ and L. mali CECT 4149. Bootstrap values appear on each node and were calculated from 1000 replications. Values $\geqslant 90 \%$ are considered statistically significant. Bar, $10 \%$ nucleotide substitution. genus Lactobacillus were between $81 \cdot 7$ and $95 \cdot 6 \%$, their closest neighbours being L. satsumensis (95.6\%), L. nagelii $(95 \cdot 3 \%)$ and $L$. mali $(95 \cdot 1 \%)$. In all three cases, the similarity in terms of the 16S rRNA gene is below the species level according to Stackebrandt \& Goebel (1994).

DNA-DNA hybridization experiments were performed by the chemiluminescent-HA method as described by Ziemke et al. (1998) using genomic DNA of strain Mont $4^{\mathrm{T}}$, two representative wine strains (116 and 154), and L. mali CECT 4149 and $L$. nagelii CECT $5983^{\mathrm{T}}$. The reference DNAs were those of strains Mont $4^{\mathrm{T}}$ and 116 and the results are expressed as mean percentage values based on three independent hybridization experiments. Intraspecific hybridization assays, performed with strains Mont $4^{\mathrm{T}}, 116$ and 154, gave values over $77 \%$, thus including these strains in the same genomic species (Stackebrandt \& Goebel, 1994). The relative binding ratio values of strains 116 and 154 to strain Mont $4^{\mathrm{T}}$ were always $100 \%$ or slightly higher. Reciprocal hybridization experiments using genomic DNA of strain $116(=$ CECT 7072) as template rendered values around $77 \%$ with strain Mont $4^{\mathrm{T}}$ and $97 \%$ with strain 154 . The interspecific hybridization values of strain Mont $4^{\mathrm{T}}$ with $L$. mali CECT 4149 and $L$. nagelii CECT $5983^{\mathrm{T}}$ were 49 and $52 \%$, respectively. When reference DNA was that of strain 116 the values were slightly lower (31 and $38 \%$, respectively). All these results confirm the separate status of the wine strains at the species level.

Genotypic characterization by rRNA-based techniques (Chenoll et al., 2003; Rodas et al., 2005) showed that wine strains and reference strain Mont $4^{\mathrm{T}}$ had identical ISR profiles and amplified 16S rDNA restriction analysis (16SARDRA) patterns with any of the four restriction enzymes utilized (Supplementary Fig. S2 available in IJSEM Online), but they are peculiar profiles that allow the differentiation of this group of strains from other Lactobacillus species (Chenoll et al., 2003; Rodas et al., 2005). In addition, intraspecific differentiation by random amplified polymorphic DNA (RAPD) and RFLP-PFGE revealed the existence of three patterns, one corresponding to strain Mont $4^{\mathrm{T}}$, another shown exclusively by strain 154 and the third one shared by the remaining wine strains $(116,119,155$ and 209P). This result is consistent even when the restriction enzyme SmaI, which yielded more than 35 fragments per digestion, was used. The overall data of each strain obtained from each technique were combined on the BioNumerics software maintaining the same coefficients used for single pattern analysis (Chenoll et al., 2003; Rodas et al., 2005), and clustered using the UPGMA method. At $74 \%$ similarity all wine strains clustered together with strain Mont $4^{\mathrm{T}}$ and apart from L. mali and L. nagelii (Supplementary Fig. S2 available in IJSEM Online). Strains 116, 119, 155 and 209P grouped together at $98 \%$ similarity and strains Mont $4^{\mathrm{T}}$ and 154 at $76 \%$ similarity. The calculated global cophenetic correlation value for the global analysis was $1 \cdot 00$, indicating an excellent level of reliability.

All data reported here confirm that strain Mont $4^{\mathrm{T}}$ and the wine strains constitute a novel taxon in the genus Lactobacillus at the species level. It is well isolated in terms of genomic similarity from its closest phylogenetic neighbours, and readily recognizable by their phenotypic characteristics, in agreement with the criteria of Wayne et al. (1987). The novel species can be phenotypically differentiated from the closest species of Lactobacillus by the properties shown in Table 1 and genotypically by ISR, 16SARDRA and RAPD profiles. The most typical physiological feature of this group of strains is the homofermentative utilization of pentoses with lactate as the sole end product, which represents a unique inducible metabolic pathway, unknown among other lactobacilli.

We propose the name Lactobacillus vini sp. nov. with strain Mont $4^{\mathrm{T}}\left(=\mathrm{DSM} 20605^{\mathrm{T}}=\right.$ CECT $\left.5924^{\mathrm{T}}\right)$, isolated from grape must by Barre in 1978, as the type strain. 
Table 1. Phenotypic traits that differ between Lactobacillus vini sp. nov. and its closest phylogenetic neighbours L. mali, L. nagelii and L. satsumensis

Species: 1, L. vini; 2, L. mali; 3, L. nagelii; 4, L. satsumensis. Data obtained in this study unless otherwise stated. +, All strains positive; -, all strains negative; DAP, diaminopimelic acid.

\begin{tabular}{|c|c|c|c|c|}
\hline Characteristic & 1 & 2 & 3 & 4 \\
\hline Growth in MRS at $15^{\circ} \mathrm{C}$ & - & + & + & + \\
\hline Growth with $5 \% \mathrm{NaCl}$ & + & - & + & + \\
\hline \multicolumn{5}{|l|}{ Fermentation of: } \\
\hline L-Arabinose & + & - & - & - \\
\hline L-Sorbose & - & - & + & + \\
\hline L-Rhamnose & - & - & + & + \\
\hline D-Mannitol & - & + & + & + \\
\hline D-Sorbitol & - & + & + & - \\
\hline Methyl $\alpha$-D-glucoside & - & - & + & + \\
\hline Salicin & + & - & + & + \\
\hline D-Cellobiose & + & + & + & - \\
\hline D-Maltose & + & - & + & + \\
\hline$\beta$-Gentiobiose & + & + & - & + \\
\hline D-Turanose & - & - & - & + \\
\hline Lactic acid isomer & $\mathrm{DL}^{*}$ & $\mathrm{~L} \dagger$ & $\mathrm{DL} \ddagger$ & LS \\
\hline Formation of exopolysaccharides from sucrose & - & $+\dagger$ & $+\ddagger$ & $+\S$ \\
\hline Peptidoglycan type & L-Lys-D-Asp & DAP & DAP & DAP \\
\hline
\end{tabular}

${ }^{\star}$ Racemic mixture.

$\dagger$ Carr \& Davies (1970).

‡Edwards et al. (2000).

§Endo \& Okada (2005).

\section{Description of Lactobacillus vini sp. nov.}

Lactobacillus vini (vi'ni. L. gen. n. vini of wine).

Gram-positive, motile, non-spore-forming rods, 0·49-0 82 $\mu \mathrm{m}$ wide by $1 \cdot 36-2 \cdot 8 \mu \mathrm{m}$ long. Cells are found singly, in pairs and in short chains. Facultatively anaerobic. Colonies on MRS agar after 4 days incubation at $28^{\circ} \mathrm{C}$ are $0 \cdot 7-1 \cdot 5$ $\mathrm{mm}$ in diameter, with entire edges, smooth, glistening and white. Catalase-negative. Growth occurs from 25 to $45^{\circ} \mathrm{C}$, but not at $15^{\circ} \mathrm{C}$ or less. Homofermentative; no gas is produced from glucose. Cells contain L-Lys-D-Asp in their peptidoglycan. DL-Lactate is exclusively produced as the end product from hexoses and pentoses. Ammonia production from arginine is variable since only strains 116 and 119 are positive. Mannitol is not produced from fructose. Exopolysaccharide is not produced from sucrose. Citric and malic acids are utilized. All strains tested ferment L-arabinose, D-glucose, D-fructose, D-mannose, $N$-acetylglucosamine, amygdalin, salicin, cellobiose, maltose, sucrose, trehalose and $\beta$-gentiobiose. Aesculin is hydrolysed. None of the analysed strains ferment glycerol, erythritol, D-arabinose, Dxylose, L-xylose, D-adonitol, methyl $\beta$-D-xyloside, L-sorbose, dulcitol, inositol, mannitol, sorbitol, methyl $\alpha$-D-glucoside, lactose, melibiose, inulin, melezitose, D-raffinose, starch, glycogen, xylitol, D-turanose, D-lyxose, D-fucose, L-fucose, D-arabitol, L-arabitol, gluconate, 2-ketogluconate or 5ketogluconate.
The type strain, Mont $4^{\mathrm{T}}\left(=\mathrm{DSM} 20605^{\mathrm{T}}=\mathrm{CECT} 5924^{\mathrm{T}}\right)$, was isolated from fermenting grape must in 1978 by $\mathrm{P}$. Barre. Reference strains are 116 (=CECT 7072) and 154 (=CECT 7073), both isolated from fermenting Spanish grape musts (Rodas et al., 2005). Strains 119, 155 and 209P are also strains of this species. The type strain shows the following additional traits: it does not produce ammonia from arginine, it ferments D-ribose, it does not ferment Dgalactose, methyl $\alpha$-D-mannoside or D-tagatose, it is unable to hydrolyse arginine and it does not split arbutin. The $\mathrm{G}+\mathrm{C}$ content is $39 \cdot 4 \mathrm{~mol} \%$.

\section{Acknowledgements}

This work has been partially supported by Comisión Interministerial de Ciencia y Tecnología (CICYT) ALI97-1077-C02-01, AGL20000827-C02-01 and AGL2000-1462. A. M. R. was supported by a grant of Conselleria d'Educació i Ciència, of Generalitat Valenciana, FPI98AG03-179. E. C. is the recipient of a PhD fellowship I3P-BPD2001-1 from the Consejo Superior de Investigaciones Científicas (CSIC). We thank CECT for reference cultures and R. Mañes for helping in the physiological characterization.

\section{References}

Barre, P. (1978). Identification of thermobacteria and homofermentative, thermophilic, pentose-utilizing lactobacilli from high temperature fermenting grape musts. J Appl Bacteriol 44, 125-129. 
Carr, J. G. \& Davies, P. A. (1970). Homofermentative lactobacilli of ciders including Lactobacillus mali nov. spec. J Appl Bacteriol 33, 768-774.

Chenoll, E., Macián, M. C. \& Aznar, R. (2003). Identification of Carnobacterium, Lactobacillus, Leuconostoc and Pediococcus by rDNAbased techniques. Syst Appl Microbiol 26, 546-556.

Collins, M. D., Rodrigues, U., Ash, C., Aguirre, M., Farrow, J. A. E., Martinez-Murcia, A., Phillips, B. A., Williams, A. M. \& Wallbanks, S. (1991). Phylogenetic analysis of the genus Lactobacillus and related lactic acid bacteria as determined by reverse transcriptase sequencing of $16 \mathrm{~S}$ rRNA. FEMS Microbiol Lett 77, 5-12.

Davis, C. R., Wibowo, D., Eschenbruch, R., Lee, T. H. \& Fleet, G. H. (1985). Practical implications of malolactic fermentation: a review. Am J Enol Vitic 36, 290-301.

Edwards, C. G., Haag, K. M., Collins, M. D., Hutson, R. A. \& Huang, Y. C. (1998). Lactobacillus kunkeei sp. nov.: a spoilage organism associated with grape juice fermentations. J Appl Microbiol 84, 698-702.

Edwards, C. G., Collins, M. D., Lawson, P. A. \& Rodriguez, A. V. (2000). Lactobacillus nagelii sp. nov., an organism isolated from a partially fermented wine. Int J Syst Evol Microbiol 50, 699-702.

Endo, A. \& Okada, S. (2005). Lactobacillus satsumensis sp. nov. isolated from mashes of shochu, a traditional Japanese distilled spirit made from fermented rice and other starchy materials. Int J Syst Evol Microbiol 55, 83-85.

Fleet, G. H. (1993). The microorganisms of winemaking. Isolation, enumeration and identification. In Wine: Microbiology and Biotechnology, pp. 1-25. Edited by G. H. Fleet. Chur: Harwood Academic Publishers.

Frayne, R. F. (1986). Direct analysis of the major organic components in grape must and wine using high performance liquid chromatography. Am J Enol Vitic 37, 281-287.

Heimbrook, M. E., Wang, W. L. L. \& Campbell, G. (1989). Staining bacterial flagella easily. J Clin Microbiol 27, 2612-2615.

Kandler, O. (1983). Carbohydrate metabolism in lactic acid bacteria. Antonie van Leeuwenhoek 49, 209-224.

Ludwig, W., Strunk, O., Klugbauer, S., Klugbauer, N., Weizenegger, M., Neumaier, J., Bachleitner, M. \& Schleifer, K. H. (1998). Bacterial phylogeny based on comparative sequence analysis. Electrophoresis 19, 554-568.

Ludwig, W., Strunk, O., Westram, R. \& 29 other authors (2004). ARB: a software environment for sequence data. Nucleic Acids Res 32, 1363-1371.

Mesbah, M., Premachandran, U. \& Whitman, W. B. (1989). Precise measurement of the $\mathrm{G}+\mathrm{C}$ content of deoxyribonucleic acid by high-performance liquid chromatography. Int J Syst Bacteriol 39, 159-167.

Picataggio, S. K., Zhang, M., Franden, M. A., McMillan, J. D. \& Finkelstein, M. (1998). Recombinant Lactobacillus for Fermentation of Xylose to Lactic Acid and Lactate. United States Patent. Patent Number: 5,798,237.

Rodas, A. M., Ferrer, S. \& Pardo, I. (2003). 16S-ARDRA, a tool for identification of lactic acid bacteria isolated from grape must and wine. Syst Appl Microbiol 26, 412-422.

Rodas, A. M., Ferrer, S. \& Pardo, I. (2005). Polyphasic study of wine Lactobacillus strains: taxonomic implications. Int J Syst Evol Microbiol 55, 197-207.

Sponholz, W. R. (1993). Wine spoilage by microorganisms. In Wine: Microbiology and Biotechnology, pp. 395-420. Edited by G. H. Fleet. Chur: Harwood Academic Publishers.

Stackebrandt, E. \& Goebel, B. M. (1994). Taxonomic note: a place for DNA-DNA reassociation and 16S rRNA sequence analysis in the present species definition in bacteriology. Int J Syst Bacteriol 44, 846-849.

Wayne, L. G., Brenner, D. J., Colwell, R. R. \& 9 other authors (1987). International Committee on Systematic Bacteriology. Report of the ad hoc committee on reconciliation of approaches to bacterial systematics. Int J Syst Bacteriol 37, 463-464.

Wibowo, D., Eschenbruch, R., Davis, C. R., Fleet, G. H. \& Lee, T. H. (1985). Occurrence and growth of lactic acid bacteria in wine - a review. Am J Enol Vitic 36, 302-313.

Ziemke, F., Höfle, M. G., Lalucat, J. \& Roselló-Mora, R. (1998). Reclassification of Shewanella putrefaciens Owen's genomic group II as Shewanella baltica sp. nov. Int J Syst Bacteriol 48, 179-186. 